\title{
Pliocene diatom and sponge spicule oxygen isotope ratios from the Bering Sea: isotopic offsets and future directions
}

\author{
A. M. Snelling ${ }^{1}$, G. E. A. Swann ${ }^{2}$, J. Pike ${ }^{3}$, and M. J. Leng ${ }^{1,2}$ \\ ${ }^{1}$ NERC Isotope Geosciences Facilities, British Geological Survey, Keyworth, Nottingham NG12 5GG, UK \\ ${ }^{2}$ School of Geography University of Nottingham, University Park, Nottingham NG7 2RD, UK \\ ${ }^{3}$ School of Earth and Ocean Sciences, Cardiff University, Main Building, Park Place, Cardiff CF10 3AT, UK \\ Correspondence to: A. M. Snelling (asnel@bgs.ac.uk)
}

Received: 2 April 2014 - Published in Clim. Past Discuss.: 12 May 2014

Revised: 6 August 2014 - Accepted: 10 September 2014 - Published: 16 October 2014

\begin{abstract}
Oxygen isotope analyses of different size fractions of Pliocene diatoms $\left(\delta^{18} \mathrm{O}_{\text {diatom }}\right)$ from the Bering Sea show no evidence of an isotope offset and support the use of bulk diatom species samples for palaeoceanographic reconstructions. Additional samples containing concentrations of sponge spicules produce $\delta^{18} \mathrm{O}$ values several per mille (\%o) lower than $\delta^{18} \mathrm{O}_{\text {diatom }}$ with a calculated mean offset of $3.9 \% \pm \pm 1.5$. This difference is significantly greater than modern-day variations in water $\delta^{18} \mathrm{O}$ through the regional water column. Despite the potential for oxygen isotope disequilibrium within $\delta^{18} \mathrm{O}_{\text {sponge }}$, there appears to be some similarity between $\delta^{18} \mathrm{O}_{\text {sponge }}$ and a global stacked benthic $\delta^{18} \mathrm{O}_{\text {foram }}$ record. This highlights the potential for $\delta^{18} \mathrm{O}_{\text {sponge }}$ in palaeoenvironmental research at sites where carbonates are not readily preserved.
\end{abstract}

\section{Introduction}

The use of oxygen isotopes in palaeoenvironmental research is well documented for both lacustrine and marine environments, predominantly from carbonate fossils, but more recently from siliceous microfossils (Emiliani, 1955; Duplessy et al., 1988; Leng and Marshall, 2004; Lisiecki and Raymo, 2007). Of the latter, diatoms (unicellular algae with a siliceous skeleton; class Bacillariophyceae) are most widely used for oxygen isotope analysis with numerous studies showing how changes in the oxygen isotope ratio of diatom silica $\left(\delta^{18} \mathrm{O}_{\text {diatom }}\right)$ reflect changes in temperature and the $\delta^{18} \mathrm{O}$ of ambient water $\left(\delta^{18} \mathrm{O}_{\text {water }}\right)$ (Shemesh et al., 1992; Swann and Leng, 2009). The majority of this work has also shown that there are few, or no, intra- or inter-species isotope offsets in diatoms (e.g. Shemesh et al., 1995; Schmidt et al., 2001; Moschen et al., 2005; Dodd and Sharp, 2010), although Swann et al. $(2007,2008)$ have shown offsets of up to $3.5 \%$ o between different size fractions of Plioceneand Quaternary-age diatoms from the subarctic North Pacific Ocean.

Another form of biogenic silica commonly found in sediments is siliceous sponge spicules (structural elements which support the skeleton of the animal; phylum Porifera, classes Demospongiae and Hexactinellida). Sponge spicules come in a variety of shapes and sizes, ranging from micrometres to metres long (Uziz et al., 2003; Jochum et al., 2012), and are often seen as needle-like structures with a hollow central canal (axial canal) (Müller et al., 2007). The crystalline nature of the sponge spicule is similar to that of diatoms (Sandford, 2003); however, the processes involved in their synthesis are different. Diatom frustules are formed from an organic template onto which a supersaturated solution of silicic acid is deposited, supplemented by passive diffusion across the cell membrane (Thamatrakoln and Hildebrand, 2008), whereas sponge spicules are formed in an enzymatic way, using silicateins, within the sponge organism (Maldonado et al., 2011; Wang et al., 2012). Additionally, diatoms live in the photic zone of the water column whereas sponges are entirely benthic organisms, so the two groups of organisms reflect environmental conditions in different parts of the water column. The use of oxygen isotope analysis of sponge spicules $\left(\delta^{18} \mathrm{O}_{\text {sponge }}\right)$ is rare, and those studies that have been carried out suggest that oxygen isotope fractionation between sponge spicules and seawater is not systematically reliable, 


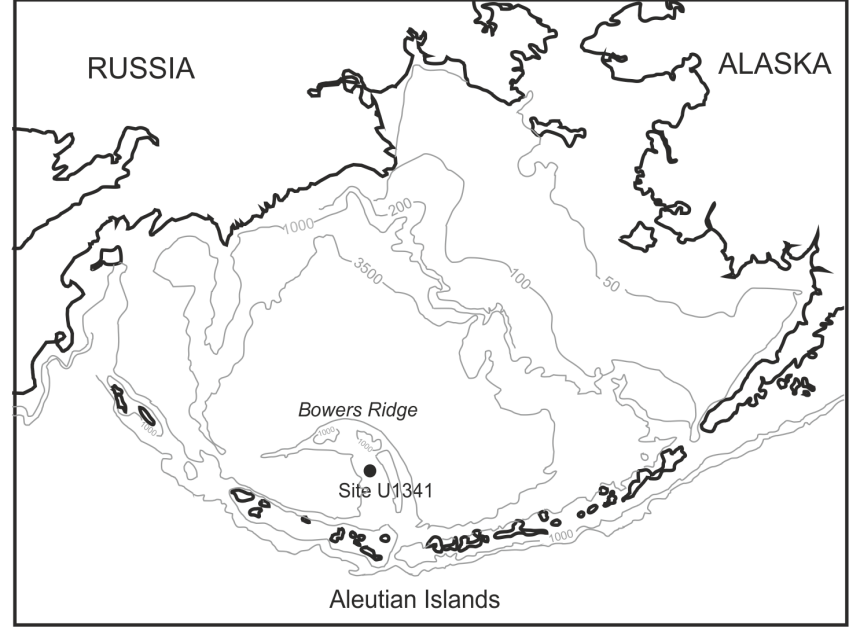

Figure 1. Location of IODP Site U1341 in the Bering Sea (Expedition 323 Scientists, 2010).

although some studies show clear trends in $\delta^{18} \mathrm{O}$ (Matheney and Knauth, 1989; Matteuzzo et al., 2013).

In this study we analyse Pliocene-age biogenic silica from the Bering Sea (2.8-2.6 Ma) to assess (1) whether oxygen isotopic offsets exist between different diatom size fractions and (2) whether siliceous sponges can be used as a tracer of bottom water conditions. Answers to these questions will (1) resolve current uncertainty regarding the palaeoenvironmental potential for $\delta^{18} \mathrm{O}_{\text {diatom }}$ in Pliocene/early Quaternary sediment samples comprised of bulk diatom species and (2) determine whether $\delta^{18} \mathrm{O}_{\text {sponge }}$ can be used to produce complementary benthic $\delta^{18} \mathrm{O}$ records alongside planktonic records of $\delta^{18} \mathrm{O}_{\text {diatom }}$.

\section{Materials and methods}

The Bering Sea is a large marginal sea (Hood, 1983; Takahashi, 2005) and, due to its semi-isolated nature, is highly sensitive to both environmental and climatic change (Takahashi et al., 2011). This study uses samples from IODP (International Ocean Discovery Program) Site U1341 $\left(54^{\circ} 2.0^{\prime} \mathrm{N}, 179^{\circ} 0.5^{\prime} \mathrm{E}\right)$, which is located in the southern part of the Bering Sea, on the western flank of Bowers Ridge at a water depth of c. $2140 \mathrm{~m}$ (Fig. 1) (Expedition 323 Scientists, 2010). The age model for IODP Site U1341 is derived from the orbital tuning of $\mathrm{U}_{37}^{k}$ records against the LR04 stacked benthic $\delta^{18} \mathrm{O}$ record (G. Bartoli, personal communication, 2013). Over the analysed interval, 2.8-2.5 Ma, sediment samples are dominated by diatom ooze (with high taxonomic diversity and good frustule preservation) and a variety of sponge spicules, which are abundant at this time and tend to be associated with more fragmented diatoms (Onodera et al., 2012; Aiello and Ravelo, 2012).
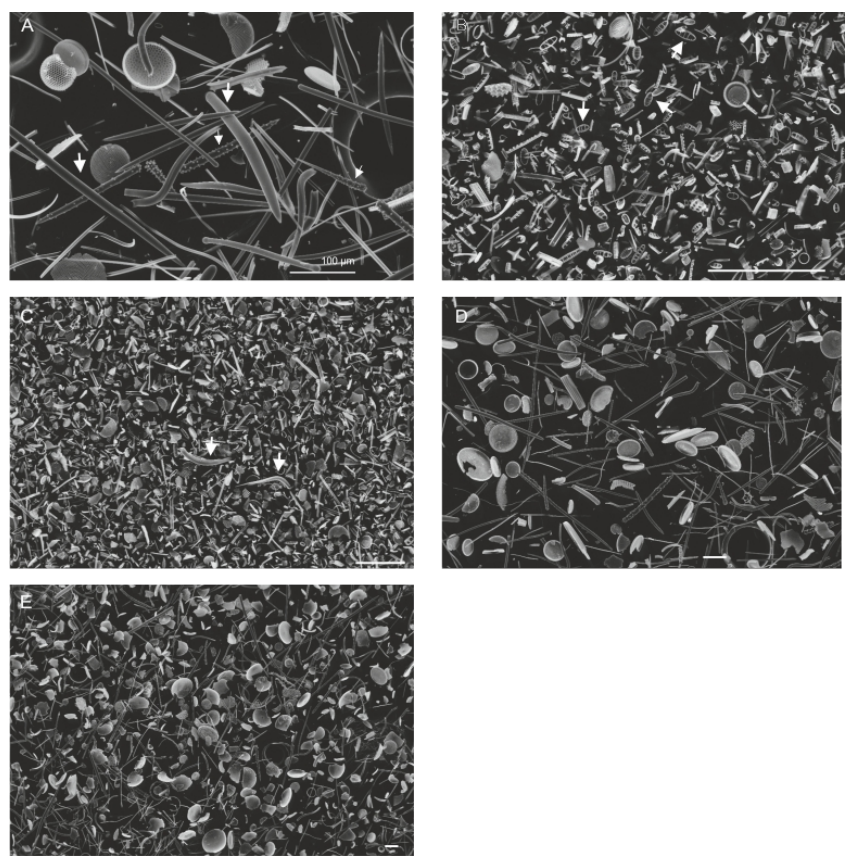

Figure 2. Examples of sample composition from SEM images: (a) examples of sponge spicules from the $>38 \mu \mathrm{m}$ fraction of sample BS77 $>38 \mu \mathrm{m}$ highlighted by arrows; (b) an example of the composition of the smaller size fraction with an abundance of $\mathrm{NeO}$ denticula seminae and Neodenticula koizumii indicated by arrows, BS77 3-15 $\mu$; (c) an example of the smaller size fraction with fragments of larger frustules as well as Proboscia spp. (indicated), Thalassionema spp. and Thalassiothrix spp. BS48 3-15 $\mu \mathrm{m}$; (d) detailed view of the $>38 \mu \mathrm{m}$ fraction showing the range of diatoms, BS77 > $38 \mu \mathrm{m}$; and (e) overview of the $>38 \mu \mathrm{m}$ fraction with examples of Coscinodiscus marginatus, Actinocyclus spp., Proboscia spp. Thalassionema spp. and Thalassiothrix spp. BS242 > 38. All scale bars $=100 \mu \mathrm{m}$ (see Supplement Table S1 for sample depths).

Forty-two sediment samples were prepared for biogenic silica $\delta^{18} \mathrm{O}$ analysis using standard techniques (Morley et al., 2004) refined for marine samples (Swann et al., 2008). Samples were sieved at $38 \mu \mathrm{m}, 15 \mu \mathrm{m}$ and $3 \mu \mathrm{m}$ to isolate sponge spicules and diatoms from the sediment with the $>38 \mu \mathrm{m}$ and $3-15 \mu \mathrm{m}$ size fractions retained for analysis. All samples were screened using a Zeiss Axiovert $40 \mathrm{C}$ inverted microscope (Morley et al., 2004) using 20 quadrants on a $100 \mu \mathrm{m} \times 100 \mu \mathrm{m}$ grid graticule, to ascertain the relative proportions (area ratio) of diatom and sponge spicule (Supplement Table S1). Relative biovolumes were calculated following Hillebrand et al. (1999) for 16 samples, with the median biovolume for sponges and diatoms in each sample multiplied by their relative proportion. Ten randomly selected samples were checked for purity using scanning electron microscope (SEM) images and X-ray fluorescence (XRF) analysis (Fig. 2, Table S1). Samples were analysed following a step-wise fluorination procedure, using $6 \mathrm{mg}$ of sample (Leng and Sloane, 2008) with isotope ratios measured using 
A

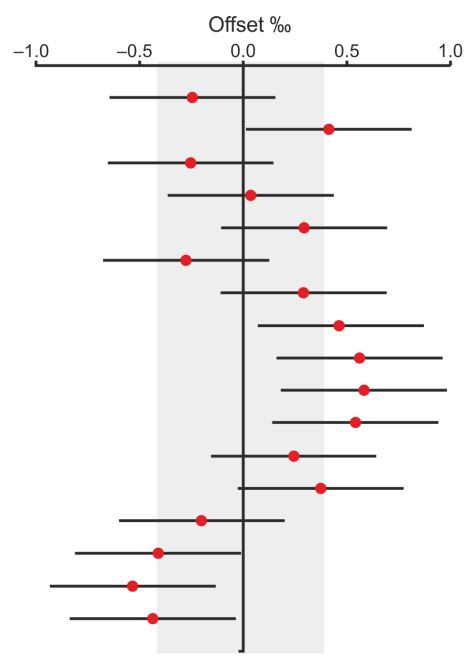

B

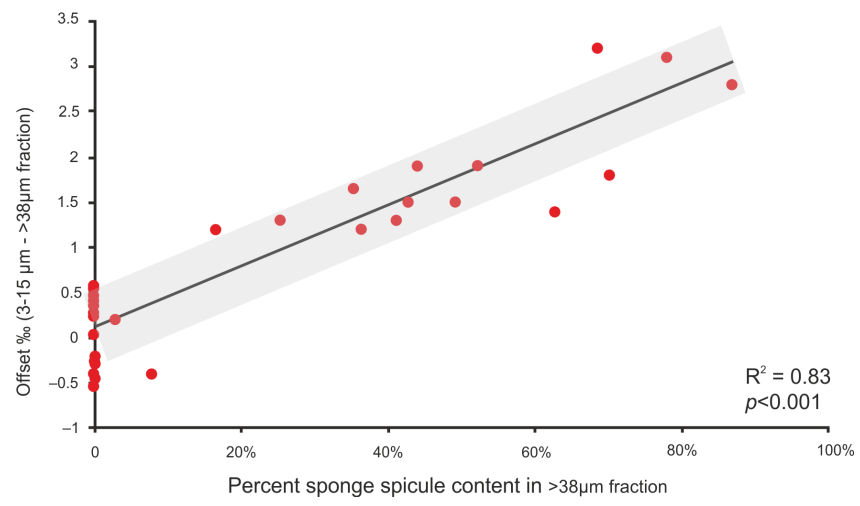

Figure 3. (a) The offset between the $>38 \mu \mathrm{m}$ and the $3-15 \mu \mathrm{m}$ fractions where no/negligible sponge spicules are present. The $y$ axis represents sample points, not to scale. Shaded area represents $\pm 0.4 \%$ o mean offset, and horizontal error bars for each point represent the $\pm 0.4 \%$ analytical reproducibility. (b) The relationship between the sponge content (area ratio) of the $>38 \mu \mathrm{m}$ fraction and the offset between the $\delta^{18} \mathrm{O}$ of the diatom 3-15 $\mu \mathrm{m}$ fraction and the mixed $>38 \mu \mathrm{m}$ fraction.

a Finnigan MAT 253. $\delta^{18} \mathrm{O}$ values were converted to the Vienna Standard Mean Ocean Water scale using the NERC Isotope Geosciences Laboratory within-run laboratory diatom standard $\mathrm{BFC}_{\text {mod }}$ calibrated against NBS28. This method has been verified through an inter-laboratory calibration exercise (Chapligin et al., 2011) with replicate analyses of sample material from this current study indicating an analytical reproducibility (mean difference) of $0.4 \% o(1 \sigma=0.3, n=10)$.

\section{Results}

\subsection{Sample composition}

All analysed samples were free of mineral and organic matter contamination, as shown by SEM (Fig. 2) and verified by $\mathrm{XRF}$ analyses, with aluminium concentrations in the range of $0.23-0.40 \%$ (typical fossil diatom $\mathrm{Al}$ concentrations c. $0.30 \mathrm{wt} \%$; Swann, 2010). Both percent area and biovolume were used to produce relative estimates of the ratio of diatom to sponge in the $>38 \mu \mathrm{m}$ fraction; however, neither of the methods are without error nor do they take into account the voids present in both sponges and diatoms. However in order to account for the 3-dimensional aspect of both, we have where possible calculated the biovolume. Sponge spicules were predominantly found in samples from the $>38 \mu \mathrm{m}$ fraction, constituting $0-87 \%$ by area ratio ( $0-92 \%$, biovolume) of the biogenic silica assemblage, the rest made up by diatoms (Table S1). The $3-15 \mu \mathrm{m}$ fraction is comprised almost entirely of diatom ( $>99 \%$ ), with negligible amounts of sponge spicules $(\leq 1 \%)$, except in nine samples where sponge spicules comprise between 2 and $21 \%$ (area ratio, biovolume not calculated) of the $3-15 \mu \mathrm{m}$ fraction. These nine samples were used only for comparison to the global stacked benthic $\delta^{18} \mathrm{O}_{\text {foram }}$ record (Lisiecki and Raymo, 2005) due to the mixed nature of both size fractions. The diatom composition of the $>38 \mu \mathrm{m}$ fraction is dominated by Coscinodiscus marginatus, Actinocyclus spp., Proboscia spp. Tha-

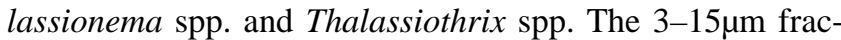
tion is composed of either fragments of larger frustules or an abundance of Neodenticula seminae and Neodenticula Koizumii species.

\subsection{Diatom and sponge $\delta^{18} \mathrm{O}$}

Comparison between $\delta^{18} \mathrm{O}_{\text {diatom }}$ from the $>38 \mu \mathrm{m}$ and 3$15 \mu \mathrm{m}$ fractions where no/negligible $(<1 \%, n=17)$ sponge spicules are present shows the isotopic offset between the two size fractions to be minimal (mean offset $=0.4 \%, 1 \sigma=$ $0.2, n=17$ ) and within analytical reproducibility. In two further samples where sponge spicule abundance in the $>38 \mu \mathrm{m}$ fraction is $1-10 \%$, offsets are also within the analytical error (sponge spicule content: $2.9 \%$; isotope offset: $0.2 \%$, sponge spicule content: $7.7 \%$; isotope offset: $-0.4 \%$ ) (Fig. 3a, Table S1). In contrast, a comparison of the $>38 \mu \mathrm{m}$ fraction (siliceous sponge spicules $10-87 \%$; diatoms $13-90 \%$ relative abundance) and the $3-15 \mu \mathrm{m}$ fraction (diatoms $\geq 99 \%$ relative abundance) reveals isotope offsets of up to $+3.2 \%$ o (mean difference $=+1.8 \%, 1 \sigma=0.7, n=14$ ). In all cases where the relative abundance of sponges is $>10 \%$, the mixed $>38 \mu \mathrm{m}$ fraction has a lower isotopic value than the diatom-rich 3-15 $\mu \mathrm{m}$ fraction. A strong linear relationship ( $p<0.001$, adjusted $R^{2}=0.83$ ) between the magnitude of the isotopic offset and the sponge spicule content in the $>38 \mu \mathrm{m}$ fraction confirms that the offset is driven by 


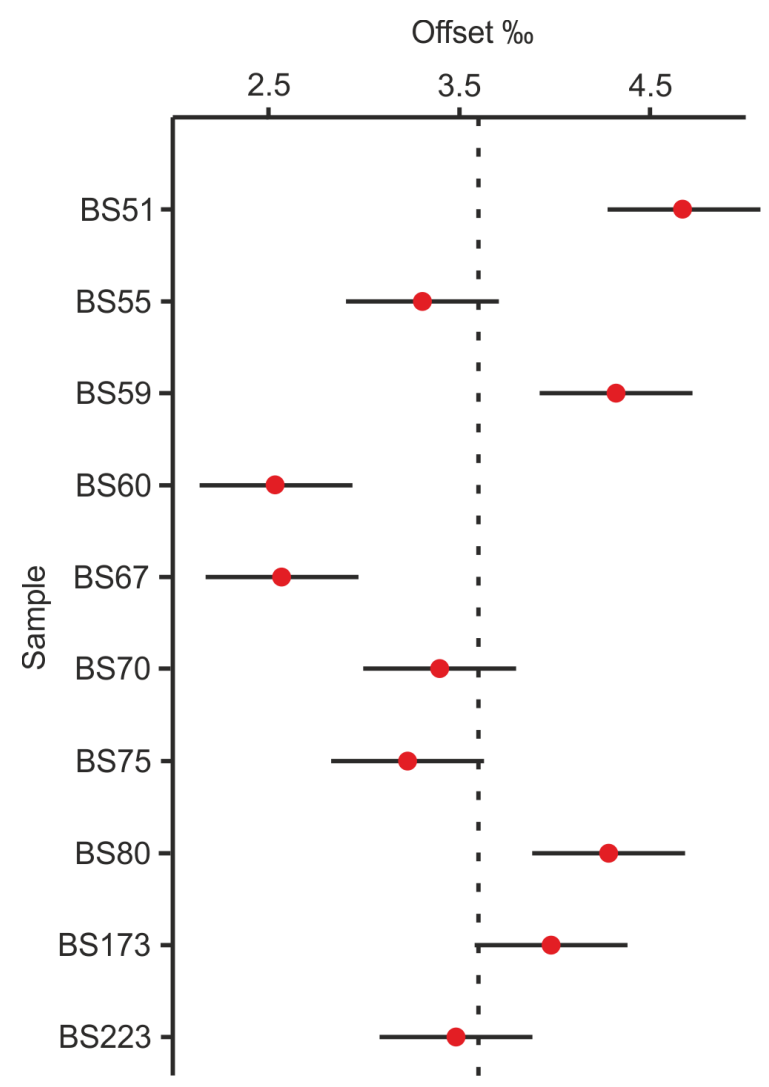

Figure 4. The offset between $\delta^{18} \mathrm{O}_{\text {diatom }}$ (from the $3-15 \mu \mathrm{m}$ fraction) and $\delta^{18} \mathrm{O}_{\text {sponge }}^{*}$ (mass balanced value for the $>38 \mu \mathrm{m}$ fraction). The horizontal error bars for each point represent the $\pm 0.4 \%$ o analytical reproducibility. The mean offset $(3.0 \%)$ is shown by the dashed line.

the relative abundance of siliceous sponge material in the $>38 \mu \mathrm{m}$ fraction, with increased siliceous sponge content leading to lower $\delta^{18} \mathrm{O}$ values (Fig. 3b) (Table S1).

It was not possible to acquire a pure sponge sample from the sediment material. In order to assess whether the offset between $\delta^{18} \mathrm{O}_{\text {diatom }}$ and $\delta^{18} \mathrm{O}_{\text {sponge }}$ is constant over time, a $\delta^{18} \mathrm{O}$ value for a pure sponge spicule sample $\left(\delta^{18} \mathrm{O}_{\text {sponge }}^{*}\right)$ was calculated by mass balancing using the relative biovolume of sponge spicules identified in the $>38 \mu \mathrm{m}$ fraction and a $\delta^{18} \mathrm{O}_{\text {diatom }}$ value obtained from the corresponding diatomrich 3-15 $\mu \mathrm{m}$ fraction (Table S1). This approach assumes that there is no $\delta^{18} \mathrm{O}_{\text {diatom }}$ isotope offset between the two size fractions (see Discussion). If we consider only those samples where the relative abundance of diatoms is less than $60 \%$ of the mixed $>38 \mu \mathrm{m}$ fraction (i.e. where there is a significant proportion of sponge present to minimise the errors from estimating the relative diatom and sponge spicule content), then modelled values of $\delta^{18} \mathrm{O}_{\text {sponge }}^{*}$ are found to be between $1.9 \%$ and $3.6 \%$ lower than $\delta^{18} \mathrm{O}_{\text {diatom }}$ (mean difference $=3.0 \%, 1 \sigma=0.6, n=8)($ Fig. 4). Despite the offset between $\delta^{18} \mathrm{O}_{\text {diatom }}$ and $\delta^{18} \mathrm{O}_{\text {sponge }}$ varying by $>1.5 \%$ and the small number of samples studied, the general trend of the $\delta^{18} \mathrm{O}_{\text {diatom }}$ and $\delta^{18} \mathrm{O}_{\text {sponge }}^{*}$ records are similar over the analysed time $\left(R^{2}=0.60, p<0.05\right)$.

\section{Discussion}

Comparisons of $\delta^{18} \mathrm{O}_{\text {diatom }}$ between different size fractions of Pliocene Bering Sea diatom samples containing a mixture of species show minimal, within $1 \sigma$ analytical error, isotope offsets. This implies that bulk species samples from different size fractions can be used for $\delta^{18} \mathrm{O}_{\text {diatom }}$ analysis on Pliocene and early-Quaternary deposits from this site. Previous work in the North Pacific (ODP Site 882) has shown offsets in $\delta^{18} \mathrm{O}_{\text {diatom }}$ of up to $3.5 \%$ between different size fractions (Swann et al., 2007, 2008), each containing a mixture of species. The mechanisms governing these offsets in size fractions of $>75 \mu \mathrm{m}$ are still unresolved, but may be connected with growth effects associated with larger diatoms (Schmidt at al., 2001). Whilst a recent study has identified offsets of up to $4.2 \%$ between different diatom taxa in sediments from the Antarctic coastal margin, this is linked to their habitat within the vertical water column rather than an inter-species effect related to different fractionation in individual taxa (Swann et al., 2013). A similar scenario cannot occur here in the Bering Sea as intra-seasonal water column variations in $\delta^{18} \mathrm{O}$ vary by less than $0.5 \%$ over a depth of 0-1188 m (Schmidt et al., 1999). Whilst caution should remain when analysing bulk samples for $\delta^{18} \mathrm{O}_{\text {diatom }}$, the lack of any significant offset in this study between two size fractions points towards the absence of a habitat-, species- or sizerelated vital/disequilibrium effect in the Bering Sea. Therefore samples from the mixed species, pure diatom, 3-15 $\mu \mathrm{m}$ fraction, can be used in future palaeoenvironmental interpretations.

The formation of sponge spicules is a complex process involving both an intracellular phase followed by an extracellular phase using two mechanistically independent biosilica condensation/deposition processes (Wang et al., 2012). These processes culminate in a hardening of the spicule through the removal of water, and it is thought that this may influence the morphology of the spicule. Sponges are further complicated by their ability to rapidly regenerate large portions of their body (Maldonado et al., 2011). The oxygen isotope composition of siliceous sponge spicules and their application to palaeoenvironmental reconstructions is relatively understudied and undefined. No estimates exist for a $\delta^{18} \mathrm{O}_{\text {sponge }}$ fractionation factor, and there is no indication of whether fractionation may vary between species. It is also not clear how interchangeable the oxygen within the hydrous layers is within $\mathrm{Si}-\mathrm{O}-\mathrm{Si}$ molecules or how $\delta^{18} \mathrm{O}_{\text {sponge may }}$ be affected by formation/regeneration processes. The few $\delta^{18} \mathrm{O}_{\text {sponge }}$ studies that have been carried out on modern marine and lacustrine samples have highlighted these complexities and suggested that sponges do not fractionate oxygen in isotopic equilibrium with ambient water with the magnitude 


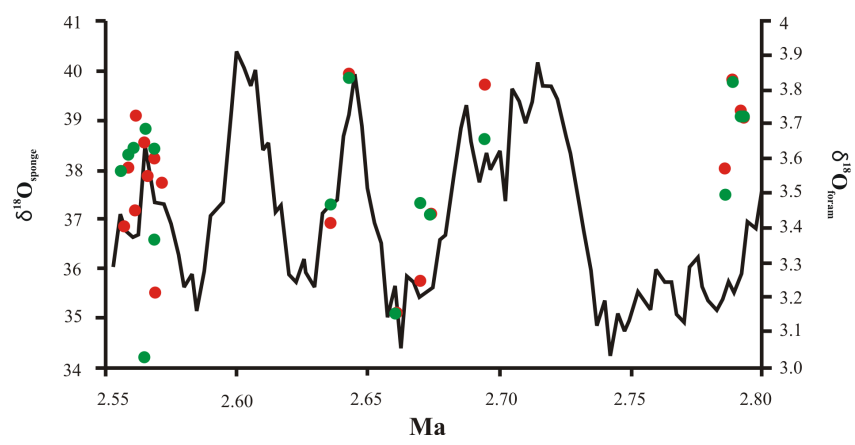

Figure 5. $\delta^{18} \mathrm{O}_{\text {sponge }}^{*}$ (mass balanced value for the $>38 \mu \mathrm{m}$ fraction) plotted through time for area (red circle) and biovolume (green circle) with a global stacked benthic $\delta^{18} \mathrm{O}_{\text {foram }}$ record (solid black line) (Lisiecki and Raymo, 2005).

of any fractionation liable to vary between seasons (Matheney and Knauth, 1989; Matteuzzo et al., 2013).

Here we have shown that $\delta^{18} \mathrm{O}_{\text {sponge }}^{*}$ is consistently lower than $\delta^{18} \mathrm{O}_{\text {diatom }}$ and that the difference between planktonic $\delta^{18} \mathrm{O}_{\text {diatom }}$ and that benthic $\delta^{18} \mathrm{O}_{\text {sponge }}^{*}$ can vary between $1.9 \%$ and $3.6 \%$ over the late Pliocene/early Quaternary (Fig. 4). Differences in $\delta^{18} \mathrm{O}$ between benthic and planktonic organisms are to be expected, but this difference is significantly greater than the $0.5 \%$ variation in the water column at the nearest site for which modern-day data exist $\left(53.1^{\circ} \mathrm{N}\right.$, $177.31^{\circ}$ E; Schmidt et al., 1999). Consequently, at the very least, this suggests different $\delta^{18} \mathrm{O}$ fractionation factors between diatoms and sponges even when taking into account possible late Pliocene/early Quaternary changes in the water column gradient. The question remains of whether long-term changes in $\delta^{18} \mathrm{O}_{\text {sponge }}$ are tracking bottom water changes. No benthic foraminifera $\delta^{18} \mathrm{O}$ record exists for this site, although the general trend of $\delta^{18} \mathrm{O}_{\text {sponge }}^{*}$ through this interval is comparable to a global stacked benthic $\delta^{18} \mathrm{O}_{\text {foram }}$ record (Lisiecki and Raymo, 2005) (Fig. 5). This is only based on a limited number of samples but clearly hints towards the sponge spicules following a predefined trend and therefore potentially carrying a palaeoenvironmental signal reflecting bottom water changes. However, it should be noted that whereas $\delta^{18} \mathrm{O}_{\text {sponge }}^{*}$ varies by $5.8 \%$ over the analysed time frame, the stacked benthic $\delta^{18} \mathrm{O}_{\text {foram }}$ alters by only $0.8 \%$. Such differences are too great to be explained by local changes in bottom water conditions.

Our results suggest that it is most likely that there is some form of non-equilibrium fractionation associated with the precipitation of silica within sponge spicules. This is not a new observation, as Matheney and Knauth (1989) reported variations of c. $2 \%$ o between sponge species growing in the same conditions from both Jamaica and Hawaii and Matteuzzo et al. (2013) recorded variations of up to $3.6 \%$ from a single species from a lake in Brazil, with the potential for intra-annual variations of over $5 \%$. Whilst these studies con- clude that sponge spicules are not formed in isotopic equilibrium with the ambient water, our evidence suggests that changes in bottom water conditions are being broadly captured by $\delta^{18} \mathrm{O}_{\text {sponge }}$. This is despite the presence of multiple taxa which have the potential to further obscure any environmental signal via inter-species variations in the fractionation of $\delta^{18} \mathrm{O}_{\text {water }}$.

\section{Conclusions}

Here we show that bulk (mixed species) diatom samples from the Bering Sea can be used to investigate the palaeoenvironment from $\delta^{18} \mathrm{O}_{\text {diatom }}$ with no discernible size or species effect. We have also identified that, at this site, sponge spicule silica has a lower $\delta^{18} \mathrm{O}$ value and therefore lower fractionation factor than diatom silica. Previous work has suggested that due to kinetic fractionation mechanisms sponges do not fractionate ambient water in isotopic equilibrium, suggesting $\delta^{18} \mathrm{O}_{\text {sponge }}$ is not a reliable proxy for palaeoenvironmental reconstructions. However, in this study, $\delta^{18} \mathrm{O}_{\text {sponge }}^{*}$ appears to follow the trend of the global stacked benthic $\delta^{18} \mathrm{O}_{\text {foram }}$ record of Lisiecki and Raymo (2005). We therefore conclude that $\delta^{18} \mathrm{O}_{\text {sponge }}$ has the potential to be used in palaeoenvironmental research.

\section{The Supplement related to this article is available online at doi:10.5194/cp-10-1837-2014-supplement.}

Acknowledgements. We would like to thank Hilary Sloane for assistance with the sample analysis and Gretta Bartoli for providing information on the age model used in this paper. This work was funded through NERC grant NE/I005889/1.

Edited by: T. Kiefer

\section{References}

Aiello, I. W. and Ravelo, C.: Evolution of marine sedimentation in the Bering Sea since the Pliocene, Geosphere, 8, 1231-1253, 2012.

Chapligin, B., Leng, M., Webb, E., Alexandre, A., Dodd, J., Ijiri, A., Lucke, A., Shemesh, A., Abelmann-Gersonde, A., Herzschuh, U., Longstaffe, F., Meyer, H., Moschen, R., Okazaki, Y., Rees, N., Sharp, Z., Sloane, H., Sonzogni, C., Swann, G., Sylvestre, F., Tyler, J., and Yam, R.: Inter-laboratory comparison of oxygen isotope compositions from biogenic silica, Geochim. Cosmochim. Ac., 75, 7242-7256, 2011. 
Dodd, J. P. and Sharp, Z. D.: A laser fluorination method for oxygen isotope analysis of biogenic silica and a new oxygen isotope calibration of modern diatoms in freshwater environments, Geochim. Cosmochim. Ac., 74, 1381-1390, 2010.

Duplessy, J.-C., Shackleton, N. J., Fairbanks, R. J., Labeyrie, L. D., Oppo, D., and Kallel, N.: Deepwater source variation during the last climatic cycle and their impact on the global deepwater circulation, Paleoceanography 3, 343-360, 1988.

Emiliani, C.: Pleistocene temperatures, J. Geol., 63, 538-578, 1955.

Expedition 323 Scientists: Bering Sea paleoceanography: PliocenePleistocene paleoceanography and climate history of the Bering Sea. IODP Prel. Rept., 323, doi:10.2204/iodp.pr.323.2010, 2010.

Hillebrand, H., Dürselen, C.-D., Kirschtel, D., Pollingher, U., and Zohary, T.: Biovolume calculation for pelagic and benthic microalgae, J. Phycol., 35, 403-424, 1999.

Hood, D. W.: The Bering Sea, in: Estuaries and Enclosed Seas, edited by: Ketchum, B. H., Elsevier Sci. Pub. Co., 337-373, 1983.

Jochum, K. P., Wang, X., Vennemann, T. W., Sinha, B., and Müller, W. E. G.: Siliceous deep-sea sponge Monorhaphis chuni: A potential paleoclimate archive in ancient animals, Chem. Geol., 300/301, 143-151, 2012.

Leng, M. J. and Marshall J. D.: Palaeoclimate interpretation of stable isotope data from lake sediment archives, Quat. Sci. Rev., 23, 811-831, 2004.

Leng, M. J. and Sloane, H. J.: Combined oxygen and silicon isotope analysis of biogenic silica, J. Quat. Sci., 23, 313-319, 2008.

Lisiecki, L. E. and Raymo, M. E.: Plio-Pleistocene climate evolution: trends and transitions in glacial cycle dynamics, Quat. Sci. Rev., 26, 56-69, 2007.

Maldonado, M., Navarro, L., Grasa, A., González, A., and Vaquerizo, I.: Silicon uptake by sponges: a twist to understanding nutrient cycling on continental margins, Nat. Scientif. Reports 1, 30, doi:10.1038/srep00030, 2011.

Matheney R. K. and Knauth L. P.: Oxygen-isotope fractionation between marine biogenic silica and seawater, Geochim. Cosmochim. Ac., 53, 3207-3214, 1989.

Matteuzzo, M. C., Alexandre, A., Varajão, A. F. D. C., VolkmerRibeiro, C., Almeida, A. C. S., Varajão, C. A. C., ValletCoulomb, C., Sonzogni, C., and Miche, H.: Assessing the relationship between the $\delta^{18} \mathrm{O}$ signatures of siliceous sponge spicules and water in a tropical lacustrine environment (Minas Gerais, Brazil), Biogeosciences Discuss., 10, 12887-12918, doi:10.5194/bgd-10-12887-2013, 2013.

Morley, D. W., Leng, M. J., Mackay, A. W., Sloane, H. J., Rioual, P., and Battarbee, R. W.: Cleaning of lake sediment samples for diatom oxygen isotope analysis, J. Paleolimnol. 31, 391-401, 2004.

Moschen, R., Lücke, A. and Schleser, G.: Sensitivity of biogenic silica oxygen isotopes to changes in surface water temperature and palaeoclimatology, Geophys. Res. Lett., 32, L07708, doi:10.1029/2004GL022167, 2005.

Müller, W. E. G., Jinhe Li, Schröder, H. C., Li Qiao, and Xiaohong Wang: The unique skeleton of siliceous sponges (Porifera; Hexactinellida and Demospongiae) that evolved first from the Urmetazoa during the Proterozoic: a review, Biogeosciences, 4, 219-232, doi:10.5194/bg-4-219-2007, 2007.
Onodera, J., Nagatomo, R., and Takahashi, K.: Diatoms, silicoflagellates, and ebridians at Site U1341 on the western slope of Bowers Ridge, IODP Expedition 323, Deep-Sea Res. Pt. II, doi:10.1016/j.dsr2.2013.03.025, 2012.

Sandford, F.: Physical and chemical analysis of the siliceous skeletons in six sponges of two groups (Demospongiae and Hexactinellida), Micros. Res. Techn., 62, 336-355, 2003.

Schmidt, G. A., Bigg, G. R., and Rohling, E. J.: Global Seawater Oxygen-18 Database, available at: http://data.giss.nasa.gov/ o18data, 1999.

Schmidt, M., Botz, R., Rickert, D., Bohrmann, G., Hall, S. R., and Mann, S.: Oxygen isotopes of marine diatoms and relations to opal-A maturation, Geochim. Cosmochim. Ac., 65, 201-211, 2001.

Shemesh, A., Charles, C. D., and Fairbanks, R. G.: Oxygen isotopes in biogenic silica: global changes in ocean temperature and isotopic composition, Science, 256, 1434-1436, 1992.

Shemesh, A., Burckle, L. H., and Hays, J. D.: Late Pleistocene oxygen isotope records of biogenic silica from the Atlantic sector of the Southern Ocean, Paleoceanography, 10, 179-196. 1995.

Swann, G. E. A.: A comparison of the $\mathrm{Si} / \mathrm{Al}$ and $\mathrm{Si}$ / time wetalkaline digestion methods for measurement of biogenic silica in lake sediments, J. Paleolimnol., 44, 375-385, 2010.

Swann, G. E. A. and Leng, M. J.: A review of diatom $\delta^{18} \mathrm{O}$ in palaeoceanography, Quat. Sci. Rev., 28, 384-398, 2009.

Swann, G. E. A., Leng, M. J., Sloane, H. J., Maslin, M. A., and Onodera, J.: Diatom oxygen isotopes: evidence of a species effect in the sediment record, Geochem, Geophy. Geosy., 8, Q06012, doi:10.1029/2006GC001535, 2007.

Swann, G. E. A., Leng, M. J., Sloane, H. J., and Maslin, M. A.: Isotope offsets in marine diatom $\delta^{18} \mathrm{O}$ over the last $200 \mathrm{ka}, \mathrm{J}$. Quat. Sci., 23, 389-400, 2008.

Swann, G. E. A., Pike, J., Snelling A. M., Leng, M. J., and Williams, M. C.: Seasonally resolved diatom $\delta^{18} \mathrm{O}$ records from the Western Antarctica Peninsula over the last deglaciation, Earth Planet. Sci. Lett., 364, 12-23, 2013.

Takahashi, K.: The Bering Sea and paleoceanography, Deep-Sea Res. Pt. II, 52, 2080-2091, 2005.

Takahashi, K., Ravelo, A. C., Alvarez Zarikian, C. A., and the Expedition 323 Scientists: Proc. IODP, 323: Tokyo (Integrated Ocean Drilling Program Management International, Inc.), 2011.

Thamatrakoln, K. and Hildebrand, M.: Silicon uptake in diatoms revisited: A model for saturable and nonsaturable uptake kinetics and the role of silicon transporters, Plant Physiol., 146, 13971407, 2008.

Uriz, M. J., Turon, X., Becerro, M. A., and Agell, G.: Siliceous spicules and skeleton frameworks in sponges: origin, diversity, ultrastructural patterns, and biological functions, Micros. Res. Techniq., 62, 279-299. 2003.

Wang, X., Schloßmacher, U., Wiens, M., Batel, R., Schröder, H. C., and Müller, W. E. G.: Silicateins, silicatein interactors and cellular interplay in sponge skeletogenesis: formation of glass fiber-like spicules, FEBS J., 279, 1721-1736, 2012. 